JANINA STANKIEWICZ

PATRYCJA ŁYCHMUS

\title{
Corporate core values and professional values \\ of Generation $Y$ from \\ the perspective of the effectiveness of ethics programs*
}

Professor Janina Stankiewicz University of Zielona Góra Patrycja Łychmus, Ph. D. University of Zielona Góra

\section{Introduction}

In business practice, expectations of the ethical conduct of employees introduced by company boards are often sustained only through sanctions resulting from the company's hierarchical structure. If, however, "the standards set in the ethical declaration of a company do not refer to specific psychological experiences of employees, characteristic of moral norms, it can be said that, from the standpoint of the organizational behavior control mode, we are dealing with a phenomenon bordering on formal management tools and custom management because of the authoritative mode of implementation, and custom because of mechanical subordination of the individual (as an answer to the question what one is supposed to - or not supposed to - do and not according to what is perceived as wrong or unjust)" (Szczupaczyński 2014). Furthermore, "to organize and improve the professional practice of people, also in business, simple validation or performance rules is not enough

* The article realized with the financial support of Zielona Gora. 
- necessary are also, and perhaps above all, one's particular dispositions" (Tomczyk-Tołkacz 2000). Agreeing with this opinion, in this paper we will refer to one of the four leading ethical systems upon which Polish business ethicists build, namely virtue ethics ${ }^{1}$. Virtue is understood as a moral advantage (narrower meaning), but also as a permanent disposition to take appropriate action that corresponds to reason (broader meaning) (Tomczyk-Tołkacz 2000, p. 184; Klimczak 1999, pp. 119-121; Zadroga 2009, p. 124). Examples of virtues mentioned by the authors in the context of business are: wisdom, justice, integrity in the sphere of intentions, declarations, actions (including those of competitors), settlements and negotiations (Tomczyk-Tołkacz 2000). Assuming that the content of formalized standards of ethical conduct in the company (ethics programs) should go beyond the realm of top-down sets of orders and prohibitions imposed by the management board ${ }^{2}$, we believe it may be effective within these programs to more directly refer to virtues - values appreciated by employees. Such activities are a chance that in the performance of their duties and tasks, organization members will be guided by specific emotions, resulting

1 The others ethical systems, referred to by Polish business ethicists are: deontologism, utilitarianism and ethics of responsibility.Deontological business ethics (also known as ethics of principles or formal ethics) assumes that the basis of one's consciousness and moral reasoning are prohibitions and orders constituting a form of regulating their behavior (Wiśniewski 1997). As per this approach, what regulates the moral conduct of employees are codes of ethics determining the scope of responsibilities and duties to be managed in order to fulfill one's professional obligations. These codes also provide a formal basis to enforce conduct that is deemed as violating the image of the profession or the company (Wiśniewski 1997). Ethical utilitarianism is concept assuming that all people are equal and equally important. In line with its recommendations, employees should act so as to optimize the balance of the system within which activities take place. In contrast to the classical, hedonistic utilitarianism, the calculation mechanism is here transferred to the plane of values (Wiśniewski 1997). However, as emphasizes B. Klimczak (2003), problematic in this approach is that, in assessing the moral conduct of an employee, one accounts only for the outcome, not the person and their motives. According to utilitarianism, the individual is prone to ethical conduct only because "ethics pays off", which makes morality instrumental. Unlike the two approaches presented above, ethics of responsibility focuses on man, their experience of their own dignity and that of others, honest (conscientious, responsible) relationship with every business partner as a human being, as well as work deemed as interpersonal relations. Referring to the theory of moral development (including Piaget, Kohlberg (Fleming 2016; Siegal 2016), it is assumed that the highest (and therefore desirable) level of moral maturity "conscientious auto-regulation of conduct." Only a "conscientious" person, says R. Wisniewski, may be responsible, whereas professional competence must go hand in hand with moral competence.

2 For more on the development, implementation and application of ethics programs within the company, as well as the shaping of ethical behavior of employees, see e.g.: Stankiewicz, Łychmus 2011a; Stankiewicz, Łychmus 2011b; Stankiewicz, Łychmus 2010; Stankiewicz, Łychmus 2009; Bortnowska et al. 2009; Stankiewicz et al. 2009; Stankiewicz, Łychmus 2007.

Corporate core values and professional values of Generation $Y$ from the perspective of the effectiveness of ethics programs 
from the evaluation of good and evil, leading to the characteristic mental sanctions, associated with moral phenomena (inner conflict, remorse, guilt) in situations where their actions have resembled unethical behavior. The presented approach nevertheless implies certain difficulties - the need to know existing attitudes toward work, values and norms that guide the employees and their inclusion in the formal standards of ethical conduct in the company, which form part of the ethical programs.

The article sets out to answer the following questions: what place do core values occupy in ethics programs of businesses; is there any relationship between them and the professional values of employees; why take into account individual preferences of organization members in terms of value when developing the agenda of corporate values. An important point of the discussion has become the values shared by those entering the labor market (the so-called Generation Y, or millennials) and the differences in this regard between them and the employees who have been pursuing their professional careers for years now (Generation $\mathrm{X}$ ). This choice is due to the fact that "older" generations are being gradually "replaced" by Ys as far as jobs are concerned. Their key role in the Polish economy are confirmed by the data from Poland's Central Statistical Office (GUS), according to which Poland is going to face an increasing problem of population aging with simultaneous gradual decline in working-age population. By 2020, we will have had 1 million - and by 2035 almost 5 million - less representatives of working-age population. Generation Y, in 2035, will comprise $75 \%$ of all human resources in organizations (Pokolenie $Y$ będzie ... 2017). Of course, we realize that not every representative of a given generation necessarily confirms its characteristics, still numerous studies have shown that generations can be ascribed a set of characteristics that are present in the majority of the people it is made up of.

\section{Professional values of Generation $\mathrm{Y}$ in light of the literature and own research analysis}

For the last few years those who qualify as the so-called Generation $Y$ have been entering the labor realm. It is predicted that the number of representatives of this generation in companies will be witnessing a steady increase (Pokolenie Y... 2016). These are people who grew up in a specific environment, being the first generation of Poles to be raised in the times of peace and the circumstances of a capitalist economy (Fazlagić 2016) which have shaped their expectations toward professional reality and influenced the values that guide their work. In

97

JANINA STANKIEWICZ

PATRYCJA ŁYCHMUS 
the future, most of them will define the labor market, replacing the "old" values and ethical norms typical for the population currently active professionally with "new" ones. The results of the analysis of the literature discovered extensive research on the values relevant to Generation Y. For instance, the authors of "The Millennial Survey 2014" (Czego oczekuje ... 2016) found that representatives of Generation Y want to work in companies that comply with the required ethical standards. They expected from their employers, above all, respect for employees and business partners, integrity and transparency, whereas from their immediate superior - fairness (To etyczne firmy ... 2016). In their view, the success of a business should be measured not only in financial performance, but also the extent to which it impacts the quality of life in society, which should be one of the main objectives of the company. In addition, they were interested in charitable activities and participation in "public life" (Czego oczekuje ... 2016). Their choices in terms of professional career, according to "The 2016 Deloitte Millennial Survey", were based on personal values. Almost half of the respondents refused working on a project that was in conflict with their personal system of values and ethical principles (The Deloitte 2016 ... 2017).

This image of Generation $Y$ has been partially confirmed by the results of surveys conducted among senior undergraduate students at the University of Zielona Gora. The study included all students studying towards Economics (89 people) and Management (59 people). Among the respondents, there were 113 women and 35 men, all aged 22-23 years. This disproportion between sexes is adequate to the structure of the population of Polish students. As can be observed from the statistics, compared with men, women are more likely to graduate from university and they constitute as much as $64 \%$ of all master's degree holders in Poland (Coraz więcej kobiet w nauce ... 2016).

The study was carried out in June 2016, using the survey technique and questionnaire as a research instrument. At that time, the respondents were about to graduate from their undergraduate courses and most of them were facing the challenges of finding employment. This stage of life was ",saturated" with expectations and ideas regarding future employers. In our view, it was conducive to clarifying the values they were guided by, making important choices about their place of employment. The overwhelming majority of the respondents (89.2\%) expected from their future employer integrity in all areas of the company's business operation. They were also sensitive to social relationships, expressed, inter alia, in their preference for such jobs that supported and promoted collaboration with other members of the organization (such opinion was expressed by almost half of the respondents - $46 \%$ ). The fourth 
part of the respondents could not imagine working in a company that does not care about the social and environmental consequences of its decisions (27\%), and a similar part (25\%) declared staying away from a company involved in unethical market practices. The clarity of the rules of operation and relationshipd with employees was appreciated by almost one fourth of the respondents $(23.7 \%)$, whereas for more than a fifth $(22.3 \%)$ the possibility of professional and personal development was important. They expected from the employer appreciation, utilization and development of individual skills and qualifications. More than one in ten respondents (12.2\%) would pay attention to whether their future work would allow maintaining a balance between professional and private life when deciding on employment.

As pointed out by some authors (Fazlagić 2008, Podwysocki 2016, Pokolenie X, $Y$... 2016), the high expectations presented by Generation $Y$ toward a career do not always find acceptance among employers. A common myth about the generation in question is "young, talented, disloyal ...". Those working with young people notice that these people, focusing on their personal needs, expect constant praise and highest ratings even if they do not make an effort (Podwysocki 2016). Many studies confirm that a "millennials are very demanding employees. From the employer, they expect opportunities for intensive development, professional challenges, a clear career path and the balance between work and personal life. However, high self-esteem, awareness of their education, often leads them to having excessive expectations in terms of salary, creating in them a demanding attitude towards the employer" (Pokolenie X, Y ... 2016). Generation Y is further attributed distance to authority arising from business hierarchy, less loyalty to the abstractly conceived organization and the expectations it formulates and more loyalty to the network of collaborators, less willingness to patiently follow a vertical career path, and a greater need for immediate feedback (Fazlagić 2008).

\section{Generation Y vs. Generation X}

The results of several studies presented in the literature indicate the existence of certain attitudes towards work, reflected in the recognized values, between Generation $Y$ and Generation X that is still active on the labor market. Hewlett et al. (2009) found, for example, that the representatives of Generation $Y$ had an increased - in comparison with the representatives of Generation X - need to recognize the meaning of the work they do, and were characterized by greater sensitivity to the social and environmental consequences of their own decisions. Millennials also appreciated more the balance between work and other spheres 
of life and recognized values, also placing more emphasis on relationships with family and loved ones and fulfilling their own passions (Banderski et al. 2009). Unlike them, the representatives of Generation X were individualists focused on career development, inclined to rivalry, corresponding to the stereotype of a participant of "the corporate rat race" (Kopeć 2017; Szymczyk 2017; Chojnowska 2017). It was also found that millennials showed more flexibility and openness to change, as well as willingness to learn and reluctance to long-term responsibilities (Hewlett et al., 2009). Compared with Generation X, Generation Y perceived life in a more intense manner, were less indifferent to the surrounding world, and to a lesser extent appreciated values such as friendship, prestige, being needed and being respected (Skarżyńska 2011).

The presented research results also point to the differences existing between the two generations with respect to moral judgments. Generation $Y$ tended to resort in their judgment to the balance of distribution, loyalty to other people and faithfulness to one's own path and purpose, while Generation X - to trust, professionalism and maintaining social relationships (Boyd 2010).

In the realm of expectations toward employers, Generation Y more often than Generation X referred to work that would guarantee them a broad autonomy, long vacation or convenient working hours. At the same time, millennials were more inclined to wish faster advancement and more brilliant career than their colleagues from Generation X, perceiving opportunities for personal growth as more important.

In the light of the cited studies, the analysis results by A. Smolbik-Jęczmien (2003) prove interesting. Aside from obvious differences between the two generations, the author also observed some similarities they share. These related specifically to such professional expectations as salary, lack of tension and pressure, stability of employment and broad autonomy. On these issues, both generations expresses the need for decent salary, working in a stress-free environment, striving for employment stability and expecting from the employer the freedom to act and independence.

\section{Corporate core values as a basis to develop an ethics program; their selection}

Systems of values held by members of organizations, which have an impact on the functioning of the company, have been the subject of numerous studies and analyzes. To quote an example, public-relations consulting firms making up the international ECCO Network, represented in Poland by On Board PR, conduct periodic research based on which reports and indexes of corporate core values 
are developed, to be later followed by organizations - Corporate Values Index (Rek 2013). Both the reports, and the resulting hierarchies of values recognized by Polish managers, have become the basis of further considerations.

Corporate core values tend to rely on a couple of pass-words (e.g. "quality", "responsibility", "loyalty") indicated by the company as key to its business. In that regard, they are like organization's own genetic code, determining the behavior of employees, internal conditions of the company and its image. When properly defined, they serve to promote certain attitudes among employees, and also facilitate the implementation of the elements of human-resources policy (e.g. recruitment, selection, assessment, remuneration, promotion). They also help build an image consistent with the company's characteristics in its environment (On Board PR ... 2010). Selection and definition of corporate core values is one of the first actions taken during the development of an ethics program in the company. Dependent on the decisions taken in this respect are the remaining elements of the program, e.g.: description of ethical and professional standards applicable in the company, formulation of the company's code of ethics and the guide of professional standards there contained, or scope of the ethics education program.

The choice of values to be recognized in the company as core should therefore stem from the analysis of the company's environment and its internal attributes, including: mission, vision, strategy, structures, procedures or market characteristics. Without their recognition, and this is something noteworthy, it is impossible to choose those values that would be essential for the company. It is on their basis that current and projected areas and scopes of organizational business operation are determined, and the same goes for which entities and persons may benefit or suffer negative consequences arising from the company's activities (e.g. owners and employees who are major stakeholders, as well as its customers, suppliers and cooperators, financial institutions and local communities). This information helps identify what the company considers important and praiseworthy, or bad and reprehensible, and thus what objects, states of affairs and situations constitute a value for it (Stankiewicz, Łychmus 2010). These conditions determining core values for employees in the organization point to the fact that, depending on the profile of the company, sets of values should be expanded by other concepts. However, as emphasized by the authors of the report Corporate Values Index 2006 (2010), it is not true. Sectoral specifics force certain variation in determining the emphasis of different issues, and often, alongside the development of companies and its area and scope of activities, concepts indicated by their owners become generalized, making 
industry differences completely blurred. The evidence of "universality" of values in business is the results of surveys conducted among Polish managers by On Board PR and "Gazeta Prawna" (On Board ... 2010). One in three respondents (36\%) considered that all companies should follow the same values, regardless of their industry, and a similar number (39\%) stated that values that companies deem most important should be the same, stressing that certain minor differences resulting from different profiles of activity are natural. The fifth part of the managers surveyed (22\%) considered that each industry has its own characteristics, and therefore their core values should not be the same, although at the same time they admitted the existence of certain fundamental values that should be recognized in all companies. Regardless of the industry, according to our previous studies (Stankiewicz, Łychmus 2010), some core values frequently mentioned by the respondents were: quality, customer satisfaction, innovation and modernity, transparency, integrity knowledge and professionalism, with their popularization among employees being usually one of the objectives of ethics programs in companies.

\section{Corporate core values and professional values of employees}

When considering the relationship between corporate core values and the professional values of employees it is necessary to adopt certain assumptions about human nature. Two main stances on this issue can be distinguished (Lewicka-Strzałecka 1997; Zadroga 2009). First, it is assumed that human decisions are determined by external conditions. Looking at it from this perspective, factors influencing employee's unethical behavior include: lack of competition, information asymmetry, transaction incidentality. Second, it is assumed that a person is autonomous and responsible for their choices, and decisions they take are done so in a free manner, in accordance with their hierarchy of values. It is therefore not possible to influence their ethical choices simply by creating favorable situational (organizational) factors. Agreeing with the second assumption, we note that the process of identification of employees with core values begins with the selection of candidates for the job. Then, by carrying out their professional duties, they are "trained" in organizational behavior, further deepened and strengthened through the system of supervision and assessment. A reflection of the desired patterns are formalized standards of ethical behavior in the company, by the means of which employees can adapt their identity to the company's requirements. They must tie their own system of values to the signals transmitted from the organization in order to blend

Corporate core values and professional values of Generation $Y$ from the perspective of the effectiveness of ethics programs 
in the latter's coherent picture. This process occurs through the mechanisms of identification, introspection and internalization (Rybak 2004). The first mechanism involves the acceptance by the employee certain values, and the resulting norms and patterns of behavior of other organization members; the second - self-assessment and self-analysis of the associated mental states, thoughts and reflections associated; and the third - their internalization, that is their adoption as one's own. Hypothetically speaking, through the process of socialization, the initial acceptance by employees of company-specific values should lead to internalization. However, the problem lies in the fact that internalization of values can prove a difficult process to employees due to factors such as their individual experiences acquired in previous jobs, personal life experiences or their personal traits (above all personal value systems, attitudes and ways of thinking). Furthermore, this process can take place at different rates, thus determining the time required to achieve satisfactory effectiveness. This process can be supported by accounting for employees' value systems in the course of defining corporate core values. An additional argument for this approach is an observation made the authors of The 2016 Deloitte Millennial Survey (2017): “There is a general feeling that everyone starts out in his or her working life as an idealist and gradually, over time, or by climbing the career ladder, they become pragmatists. Our study contradicts this thesis. It turned out that the higher the position occupied by a millennial, the more important is the role of his or her professed values".

\section{Adjusting corporate core values to professional values of millennials; examples}

The process of adjusting corporate core values to the values of Generation $Y$ employees is not necessarily associated with the change of the value agenda, which the company has been thus far identifying as core in their business. Sometimes it is enough to simply change the optics of their presentation and represent so that they "reach" young people, help them understand why they should be respected and what benefits it entails. This can be done by modifying things such as the company's code of ethics which is one of the instruments of institutionalization of ethics in the company. This document is "ideal" from the perspective discussed, as it promotes the dissemination of values and the resulting standards of conduct among employees.

The code in questions usually consists of three parts: introduction, agenda and description of core values and the resulting standards of conduct. Introduction 
(preface or preamble) tends to contain decisions on matters essential to the people in the organization, that is what attitude is expected from them towards life and the world and what it entails in terms of work. In particular, it states the following (Stankiewicz, Łychmus 2010):

- organization basis (e.g. tradition, authority, innovation),

- guidelines for employees (e.g. knowledge, experience),

- importance of hierarchy and professional posts and positions held by employees,

- perception of truth and criteria for distinguishing it from falsehood (e.g. traditions or trusted authority),

- timeline for activities undertaken by employees,

- time management in the company,

- perception of the surrounding world by employees (e.g. viewing it as challenging, threatening, difficult to control),

- form of relationships between the company and the environment,

- whether employees should strive to exercise control over the environment, or rather adapt to it or obey it,

- qualities and attitudes expected from employees (e.g. dedication, creativity, responsibility, loyalty, willingness to grow),

- desirable behavior model in the organization (e.g. whether and to what extent employees should demonstrate activity, whether they should be independent or rather obedient, etc.),

- form of interpersonal relationships in the organization - whether they should rely on the cooperation or on competition; whether the focus is teamwork or individual work; type of relationship preferred in the company - formal or informal, etc.

The above assumptions, defining the conduct of business management and the philosophy it relies on, also in the realm of expectations held towards employees, constitute the interpretation of the remaining content of the code. They indicate sources identified as core values in the company and help employees understand the resulting standards they should respect in their work.

The section of the code containing values is usually clearly separated from the others and bore by an appropriate heading and introduction (e.g. "The company regards the following to be its core values ..."), which aims to facilitate their grasping by employees and simultaneously stress their importance. Let us recall that according to the research, Polish entrepreneurs usually indicate the following values as core: quality, customer satisfaction, innovation and modernity, transparency, integrity, knowledge and professionalism. 
The section of the code containing a description of the applicable standards of organization members under core values determines to pursue what they are to strive for, what to avoid, as well as how to do it. It is a set of instructions for what the company deems good and what bad; what one is supposed to do and what they are not; what are the criteria for work performance. It makes employees aware of behavior that is encouraged, accepted or unacceptable under the assumed core values. Examples of rules specifying the standards based on the core values recognized by the Polish managers with reference to the professional values of Generation Y are shown in table 1.

\section{Table 1. Rules reflecting the values held in high esteem by Polish managers with reference to the professional values of Generation Y; examples}

\begin{tabular}{|c|c|c|}
\hline Core values & Examples of rules & $\begin{array}{l}\text { Professional values } \\
\text { of Generation } Y\end{array}$ \\
\hline Quality & $\begin{array}{l}\text { We recognize the principle of employment stability, which } \\
\text { is perceived as the essential foundation for maintaining } \\
\text { high quality of our products. }\end{array}$ & $\begin{array}{l}\text { Employment } \\
\text { security }\end{array}$ \\
\hline $\begin{array}{l}\text { Customer } \\
\text { satisfaction }\end{array}$ & $\begin{array}{l}\text { Complaints and grievances from customers/consumers } \\
\text { dissatisfied with our products/services and behavior of } \\
\text { employees are handled with a sense of full responsibility. }\end{array}$ & $\begin{array}{l}\text { Integrity and } \\
\text { responsiblity } \\
\text { towards business } \\
\text { partners }\end{array}$ \\
\hline $\begin{array}{l}\text { Innovation } \\
\text { and moder- } \\
\text { nity }\end{array}$ & $\begin{array}{l}\text { Our personnel policy aims to attract the most talented } \\
\text { people whose work will stimulate our future development. } \\
\text { The company encourages employees to compete in the } \\
\text { field of innovative solutions, and to undertake work that } \\
\text { rationalize the production process. It provides safety of } \\
\text { such actions based on the belief "no risk, no gain". Thus, } \\
\text { the company encourages teamwork and the exchange } \\
\text { of ideas between disciplines, specialties and branches to } \\
\text { further integrate the production process, while at the same } \\
\text { modernizing it. }\end{array}$ & $\begin{array}{l}\text { Self-development } \\
\text { Use of individual } \\
\text { skills and } \\
\text { qualifications } \\
\text { Cooperation } \\
\text { Professional growth }\end{array}$ \\
\hline Transparency & $\begin{array}{l}\text { The company has a transparent information policy creating } \\
\text { opportunities to submit comments by employees. } \\
\text { The management provides the owners with full and honest } \\
\text { information about the business activity. }\end{array}$ & $\begin{array}{l}\text { Participation in } \\
\text { decision-making } \\
\text { Integrity } \\
\text { Transparency }\end{array}$ \\
\hline
\end{tabular}




\begin{tabular}{l|l|l} 
Integrity & $\begin{array}{l}\text { The company adheres to the rules of fair competition in } \\
\text { order to ensure long-term positive cooperation based on } \\
\text { mutual trust. } \\
\text { The company is committed to awarding fair remuneration } \\
\text { for the work done, adequate to the job position held. }\end{array}$ & Fair competition \\
\hline Knowledge & $\begin{array}{l}\text { We wish to expand the knowledge and skills of our } \\
\text { employees through the use of our own training methods. }\end{array}$ & $\begin{array}{l}\text { Personal and } \\
\text { professional growth }\end{array}$ \\
\hline $\begin{array}{l}\text { Professiona- } \\
\text { lism }\end{array}$ & $\begin{array}{l}\text { The company attaches great importance to the } \\
\text { development of individual potential of each employee. }\end{array}$ & $\begin{array}{l}\text { Personal and } \\
\text { professional growth }\end{array}$ \\
\hline
\end{tabular}

Source: own study based on: Cieślik, Gasparski 2010; Stankiewicz, Łychmus 2010;. Walczak-Duraj 2002

The examples presented in table 1 imply the capacity to formulate policies that account for values that are important to both employers and employees. With regard to the language style of rules, stylistic forms should be adapted to cognitive skills and preferences of young people. Above all, they must be expressed in a language that is clear, concise and understandable for them. Apart from that, the rules should be realistic and stem directly from the core values. This will facilitate not only their understanding but also acceptance, thus increasing the likelihood of their practical application.

\section{Conclusion}

In order for a business activity to be ethical, one needs ethical employees. Nevertheless, the ongoing generational change leads to the situation in which the values and the resulting standards of ethical behavior that have been thus far embraced in the workplace may no longer be unacceptable or respected by young people that enter the labor market. This is not always due to the differences in the value systems of distinct generations, but rather their practical disregard in human resources management.

To liberate the potential of Generation $\mathrm{Y}$ and seize the opportunities and strengths of its representatives, managers should look at the values that guide them in their professional life also in terms of ethics. Value systems of employees have been the subject of many studies and scientific investigations, and the literature contains reports and characteristics for both generations, thus

Corporate core values and professional values of Generation $Y$ from the perspective of the effectiveness of ethics programs 
making it easier to understand the behavioral differences of "young" and "old" employees.

Learning about professional values of employees is the first step to their inclusion in the agendas of requirements posed in ethical human behavior within organizations (e.g. codes of ethics). It is common knowledge that individuals feel an inner need to apply the values and moral principles they recognize, and therefore referring to to them in the elements institutionalizing ethical behavior in the company can promote the effectiveness of business ethics programs.

\section{Summary}

Corporate core values and professional values of Generation $Y$ from the perspective of the effectiveness of ethics programs

In order for a business activity to be ethical, one needs ethical employees. Nevertheless, the ongoing generational change leads to the situation in which the values and the resulting standards of ethical behavior that have been thus far embraced in the workplace may no longer be unacceptable or respected by young people that enter the labor market. The article sets out to answer the following questions: what place do core values occupy in ethics programs of businesses; is there any relationship between them and the professional values of employees; why take into account individual preferences of organization members in terms of value when developing the agenda of corporate values. An important point of the discussion has become the values shared by those entering the labor market (the so-called Generation Y, or millennials) and the differences in this regard between them and the employees who have been pursuing their professional careers for years now (Generation X).

Keywords: corporate core values, ethics program, Generation $Y$.

\section{Streszczenie}

Kluczowe wartości firmy a zawodowe wartości pokolenia $Y$ z perspektywy skuteczności programów etycznych

Chcąc prowadzić etyczny biznes, trzeba mieć etycznych pracowników. Jednak zachodzące zmiany pokoleniowe sprawiają, że dotychczas uznawane wartości w miejscu pracy i wynikające $\mathrm{z}$ nich normy etycznego postępowania mogą być nieakceptowane 
i nierespektowane przez młode osoby, wkraczające na rynek pracy. Celem artykułu jest odpowiedź na pytania: jakie miejsce zajmują kluczowe (firmowe) wartości w programach etycznych przedsiębiorstw, czy jest związek między nimi a wartościami zawodowymi pracowników, dlaczego warto uwzględniać indywidualne preferencje członków organizacji $\mathrm{w}$ zakresie wartości podczas opracowywania katalogu wartości firmowych. Istotnym punktem rozważań stały się uznawane wartości osób wchodzących na rynek pracy (tzw. pokolenie Y) oraz różnice w tym względzie między nimi a pracownikami od lat realizującymi swoje kariery zawodowe (pokolenie X).

\section{Słowa}

kluczowe: wartości firmy, program etyczny, pokolenie Y.

\section{References}

1. Chojnowska A. (2017), Pokolenie X, Y, Z. Czym się różnia i jak się komunikują?, http://krakow.wyborcza.pl/krakow/1,44425,17056726, Pokolenie_X_ Y_Z_Czym_sie_roznia_i_jak_sie_komunikuja_html (01.01.2017 - access date).

2. Cieślik J., Gasparski W., Etyczna firma. Pakiet narzędziowy dla wdrożenia standardów etycznych w matej i średniej firmie, http:// www.cebi.pl/texty/ etycznafirma.doc (04.05.2010 - access date).

3. Coraz więcej kobiet $w$ nauce... (2016), http://www.edulandia.pl/ studia/1,118573,15945557,Coraz_wiecej_kobiet_w_nauce_Na_studiach_ dziewczyny.html (30.04.2016 - access date).

4. Corporate Values Index 2006, http://www.biznespolska.pl/files/ reports/RaportCVI20061.pdf, 25.05.2010 - access date.

5. Czego oczekuje pokolenie Y, (2016), http://it-manager.pl/czego-oczekujepokolenie-y/ (01.04.2016 - access date).

6. Fazlagić J.A. (2016), Charakterystyka pokolenia Y, http://www.e-mentor. edu.pl/artykul/index/numer/25/id/549 (29.03.2016 - access date).

7. Generacja Y - czym jest $i$ co ja wyróżnia?, (2016), http://praca.wp.pl/ title,Generacja-Y-czym-jest-i-co-ja-wyroznia,wid,14347184,wiadomosc. html (29.03.2016 - access date).

8. Klimczak B. (1999), Moralna odpowiedzialność przedsiębiorcy, „Annales. Etyka w życiu gospodarczym", Vol. 2.

9. Kopeć M. (2017), Pokolenie X i Y. Dwa różne światy - jedna drużyna, http:/ / www.treco.pl/wiedza/artykuly-szczegoly/id/836/pokolenie-x-i-ydwa-rozne-swiaty-jedna-druzyna (01.01.2017 - access date). 
10. Lewicka-Strzałecka A. (1997), Etyka biznesu jako dyscyplina naukowa, [in:], J. Dietl, W. Gasparski (red.), Etyka biznesu, PWN, Warszawa.

11. On Board PR, "Gazeta Prawna”, http://www.wartosci.pl/down/ WynikiBadanOnBoard PRiGP.pdf (25.05.2010 - access date).

12. Podwysocki P. (2016), Zrozumieć pokolenie Y, http://naszeinspiracje.com/ tematyka/dobry-wplyw/zrozumiec-pokolenie-y/ (01.04.2016 - access date).

13. Pokolenie X, Y na rynku pracy,(2016), https://kariera.sgh.waw.pl/artykuly/ spoleczenstwo/pokolenie-X-y-na-rynku-pracy (01.04.2016 - access date).

14. Pokolenie Y będzie wkrótce główna siła napędowa polskiej gospodarki, http:// www.outsourcingportal.eu/pl/pokolenie-y-bedzie-wkrotce-glowna-silanapedowa polskiej-gospodarki, (01.04.2016 - access date).

15. Rek K. (2013), Co się liczy dla firm?, „Harvard Business Review Polska” No. 122, https:/ / www.hbrp.pl/a/co-sie-liczy-dla-firm/LIVBShrT (13.01.2017 - access date).

16. Rybak M. (2004), Etyka menedżera: społeczna odpowiedzialność przedsiębiorstwa, Wyd. Naukowe PWN, Warszawa.

17. Smolbik-Jęczmień A. (2003), Podejście do pracy i kariery zawodowej wśród przedstawicieli generacji X i Y - podobieństwa i różnice, „Nauki o Zarządzaniu” vol. 1 (14), pp. 97-114.

18. Stankiewicz J., Łychmus P. (2007), Wspieranie zmian kultury organizacyjnej poprzez programy etyczne przedsiębiorstw, [in:] Prace Naukowe Akademii Ekonomicznej im. Oskara Langego we Wrocławiu, No. 1184.

19. Stankiewicz J., Łychmus P. (2010), Upowszechnienie wartości i norm społecznych wśród pracowników z wykorzystaniem kodeksu etycznego, [in:] Zeszyty Naukowe Wyższej Szkoły Bankowej we Wrocławiu, No. 19.

20. Stankiewicz J., Łychmus P. (2011a), Kodeks etyczny instrumentem upowszechniania $i$ promowania etycznej kultury organizacyjnej wśród pracowników, [in:] Zeszyty Naukowe Ostrołęckiego Towarzystwa Naukowego im. Adama Chętnika, Ostrołęka.

21. Stankiewicz J., Łychmus P. (2011b), Upowszechnianie etycznej kultury organizacyjnej w przedsiębiorstwie za pomoca programu etycznego, [in:] Zeszyty Naukowe Wyższej Szkoły Bankowej we Wrocławiu, No. 24.

22. Szczupaczyński J. (2014), Kodeksy etyczne i ich wptyw na moralne perspektywy polskich menedżerów, Acta Universitatis Lodziensis, folia Sociologica 48.

23. Szymczyk J. (2017), Pokolenie X na rynku pracy - charakterystyka, http:// poradnikprzedsiebiorcy.pl/-pokolenia-w-pracy-pokolenie-x (01.01.2017 access date).

24. The 2016 Deloitte Millennial Survey, (2017), https://www2.deloitte.com/ $\mathrm{pl} / \mathrm{pl} /$ pages/press-releases/articles/millennials-2016.html (01.01.2017 access date). 
25. To etyczne firmy przyciągną Y-greki. Wyniki badania na zlecenie Henkel Polska (2016), http://osobyzasoby.pl/2015/10/to-etycznefirmy-przyciagna-y-greki-wyniki-badania-na-zlecenie-henkel-polska/ (01.04.2016 - access date).

26. Tomczyk-Tołkacz J. (2000), Człowiek w biznesie - między pragnieniem pieniądza a cnota, "Annales. Etyka w życiu gospodarczym”, Vol. 3, pp. 183185.

27. Walczak-Duraj D. (2002), Ład etyczny w gospodarce rynkowej. Doświadczenia polskiej transformacji, Wyd. Uniwersytetu Łódzkiego, Łódź.

28. Zadroga A. (2009), Metody ujmowania etyki biznesu w Polsce, "Annales. Etyka w życiu gospodarczym", Vol. 12, No. 1, pp. 119-128. 